\title{
16 Picturing Vitality, the Crystallisation Fingerprint Method
}

\author{
Paul Doesburg \\ Crystal Lab
}

\section{CONTENTS}

Introduction.

The Crystallisation Method...

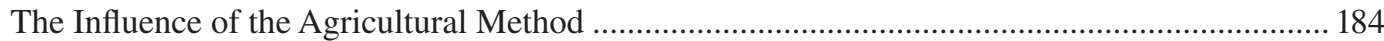

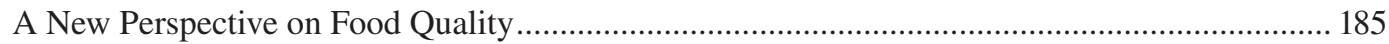

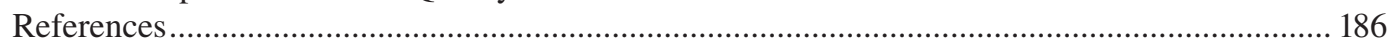

\section{INTRODUCTION}

Nowadays, food is increasingly being divided into 'good' and 'bad'. This perspective focuses on the nutrients, rather than on the products that we actually eat. This nutrient-oriented framing of food regards food quality as good when it contains few potentially harmful constituents - 'the bads' - and higher levels of health-supporting constituents - 'the goods'. Logical reasoning, right? However, when you take a closer look, this issue is somewhat more complicated, because a living organism is much more complex than a simple chain of cause-effect relations between single ingredients. Lycopene, for instance, is a major antioxidant that is widely distributed in the human body, and is thought to act as a preventive agent against prostate cancer. While isolated lycopene does appear to be effective against single prostate cancer cells grown in a Petri dish, the results from animal and human patient studies are ambiguous. A few studies demonstrated a preventive action from tomato powder (which contains lycopene), but not from isolated lycopene itself (Applegate et al., 2019; Boileau et al., 2003). Even more striking, the daily consumption of carrots by smokers appears to reduce the incidence of lung cancer, a variant on the proverb 'An apple a day keeps the doctor away'. However, when you regularly give smokers beta-carotene tablets - the most important antioxidant in carrots - the risk of developing lung cancer actually increases. Why is that? Doctors aren't completely sure about the difference between the absorption of nutrients through food and their intake as a supplement, but they do acknowledge that the relationship between diet and cancer is far more complex than simply supplementing one's daily nutrition with a few micronutrients (Whitworth, 2006).

Clearly, this cause-effect approach has provided us with a wealth of information concerning the structure and functioning of the inorganic world, but remains inadequate to understand organic aspects such as shape, self-regulation and resilience': characteristics of 'the whole plant' or 'the whole animal' from which our food originates. Living organisms permanently protect their integrity

\footnotetext{
${ }^{1}$ Vitality indicates how the 'self-regulation' of an organism is expressed as 'resilience' - resilience in the sense of 'elasticity', the capacity to cope with challenges. This may be related to the product itself or to the effect of the product on the consumer (Kahl et al., 2012). Self-regulation is the ability of organisms to adjust and maintain various physiological and other biological parameters at comparatively constant levels. Individuality is the characteristic (species-specific) nature of living organisms.
} 


\section{BOX 16.1 THE CRYSTALLISATION METHOD}

The crystallisation method was developed in the 1930s by Ehrenfried Pfeiffer (1899-1961), a German scientist, who was strongly connected to the biodynamic agricultural movement. Pfeiffer received an honorary degree of Doctor of Medicine from Hahnemann Medical College in Philadelphia in 1939 for his contribution to the development of the crystallisation method in relation to the detection and localisation of the early onset of cancer via blood samples.

against different environmental influences. Organic agricultural research works from the hypothesis that cultivation measures (fertilisation, tillage, seed variety, etc.) influence the degree to which an organism can maintain its integrity, and this has a strong correlation with the organism's health, whether plant, animal or human (Velimirov et al., 2010). Following this line of thought, a whole food product should not be reduced to a set of chemicals, but should be seen as a dynamic, hierarchically organised unit. Because of this, one could argue that the results of nutritional tests cannot be reduced to the chemical composition of the food. From a systemic biology perspective, it is acknowledged that an organism cannot be regarded as a simple chain of cause-effect relations between its different compounds, but instead as a highly complex coherent whole (Sauer et al., 2007).

\section{THE CRYSTALLISATION METHOD}

I encountered the crystallisation method in 2000 at the Dutch Louis Bolk Institute and was overwhelmed. I realised that this method makes it possible to acquire a 'fingerprint' of this extremely complex 'coherence' of our food. ${ }^{2}$ Box 16.1 describes the crystallisation method.

The method is based on the generation and subsequent evaluation of dendritic crystallisation patterns (i.e. the 'fingerprints'), which emerge when an aqueous dihydrate cupric chloride solution $\left(\mathrm{CuCl}_{2} \cdot 2 \mathrm{H}_{2} \mathrm{O}\right)$ is crystallised on a glass plate in the presence of a water-soluble additive (the sample; Busscher et al., 2010a; Gallinet and Gauthier-Manuel 1992). Additives can be single molecules as well as complex food matrices. The crystallisation patterns are additive specific (Andersen et al., 1998, 2001; Fritz et al., 2017; Kahl et al., 2014, 2016; Seidel et al., 2015; Shibata et al., 2000; Schweizer et al., 2010; Szulc et al., 2010; Vester, 1960) (see Figure 16.1) and emerge through a self-organisation process of the copper chloride $\left(\mathrm{CuCl}_{2}\right)$ which is influenced by the physical, chemical and biological properties of the additive (Busscher et al., 2010b, 2014, 2018). A remark by Rudolf Steiner, that 'spirit is never without matter, and matter is never without spirit', helps me to regard the crystallisation images as a 'manifestation' of the spiritual dimension of the organism that the pictures originate from, and the degree to which they're able to maintain their integrity.

The characteristics of the crystallisation patterns can be evaluated by human visual evaluation using defined criteria, developed according to adapted ISO norms for sensory analysis (Huber et al., 2010a; Doesburg et al., 2015), and/or by computer-based image analysis using texture or structure variables (Andersen et al., 1999; Doesburg and Nierop, 2013; Unluturk et al., 2013). This kind of fingerprint analysis has been applied to a broad range of additives, addressing different research

\footnotetext{
${ }^{2}$ Crystallisation research in the Netherlands took place at the Louis Bolk Institute in Driebergen until 2010. Since 2010, Paul Doesburg maintained an independent laboratory, Crystal Lab (https://www.crystal-lab.nl/), in the former monastery Roepaen in Ottersum (the Netherlands), which is connected to a European consortium of five crystallisation laboratories. Paul is currently rebuilding his crystallisation laboratory at the Hiscia Research Institute in Arlesheim, Switzerland.
} 


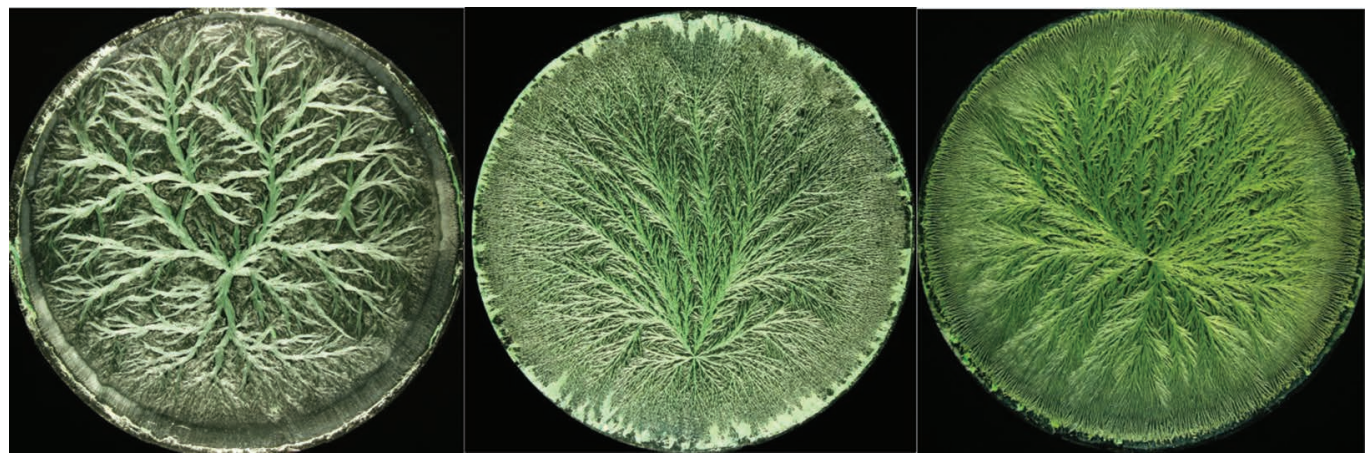

FIGURE 16.1 Product-specific crystallisation patterns of barley (left), tomato (middle) and white cabbage (right).
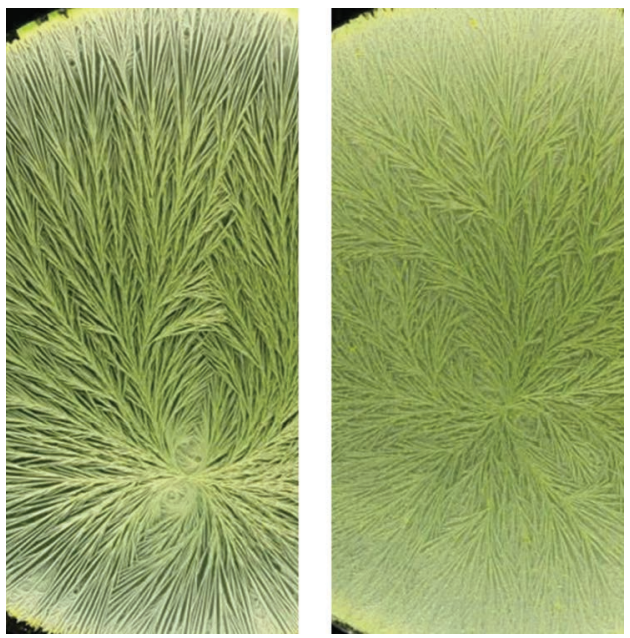

FIGURE 16.2 Crystallisation patterns of the effect of milk processing: raw unprocessed milk (left) and the same sample after homogenisation at 50 bar (right). We can see an enormous conversion of the structure of the crystallisation pattern. During homogenisation (commonly at 200-300 bar, or 200-300 kg pressure/cm2), milk is passed under high pressure through a tiny orifice. The structure and size of the fat globules in the milk are influenced by this. This means that the natural creaming of the milk, which many people find unpleasant, doesn't take place.

questions, such as the effect of innovative processing techniques (Marzaleka et al., 2019), the biological effects of ultramolecular homeopathic preparations (Baumgartner et al., 2012; Doesburg et al., 2019, 2021), the diagnosis of diabetics (Shibata et al., 2000), doping (Shibata et al., 1996), the early onset of cancer (Barth, 1990; Koopmans, 1990) and other pathologies (Piva, 1994) in human blood, but predominantly in food quality analysis. With respect to the latter, the method has been shown to reflect plant physiological processes such as ripening and decomposition (Fritz et al., 2011, 2017, 2018), the effects of processing (see Figure 16.2), feeding regimes and farming systems (Kahl et al., 2009, 2015, 2016; Seidel et al., 2015; Szulc et al., 2010) in a broad range of agricultural products, which demonstrate the method's systemic approach to food quality. The crystallisation method fits seamlessly with the principles of organic farming, in which the focus is on the development of 


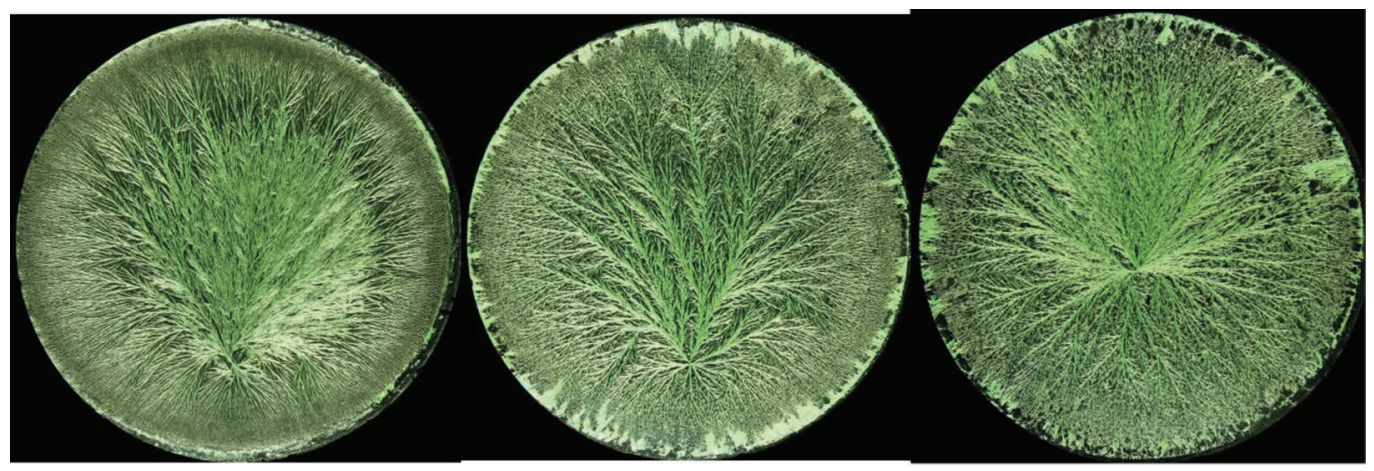

FIGURE 16.3 Crystallisation patterns of different ripening stages of vine tomatoes: unripe, little structure and condensed patterns (left); ripe, structure and cohesion (middle); and overripe, loss of structure and cohesion (right).

robust, resilient soil, crops and animals, hence the use of the crystallisation method for decades in organic and biodynamic food quality analysis.

By means of the crystallisation method, I aim to deduce more about the quality of food than solely the nutrient content. The method allows you to visualise differentiation and ageing statuses in agricultural products (see Figure 16.3). Particularly in ageing experiments (based on sample ageing or processing), it is striking to see how crystallisation patterns fall apart and lose their cohesion. This corresponds perfectly with the image one would generally associate with a loss of structure. Consequently, quality is literally made visible (see Figure 16.4).

The images are evaluated in two different ways: visually and by means of computerised image analysis (Andersen et al., 1999; Doesburg and Nierop, 2013). Depending on the research question, we choose one of the two methods or a combination. Computerised analysis allows us to find significant differences between products or treatments, allows the analysis of large datasets and is regarded as 'objective' which aids communication within the scientific arena. However, this approach misses the nuances of the method which are captured with a visual evaluation. For this, standardised evaluation criteria have been developed and validated within a European collaboration between several crystallisation laboratories according to adapted ISO norms for sensory panels (Huber et al., 2010a). Herewith, the general characteristics - the phenomena of a crystallisation image - can be described. The empirical basis of the visual evaluation of the crystallisation patterns is that the degree of wholeness of a sample is in some way transferred to the microscopic and macroscopic arrangement of the crystal needles. Wholeness in such is the degree to which the sample is capable of forming a hierarchically organised unit.

As reflected in the photos of the ageing carrot juices or the wheat derived from different farming systems (see Figures 16.4 and 16.6), an increasing degree of wholeness generates a better coordinated pattern with a stronger perradiation ${ }^{3}$ and a higher degree of regularity in the branching frequency and in the onset and angle of the side needles. Generally, this is observed as a higher degree of harmony in the image.

Currently, I am involved in establishing a scientifically communicable manner to evaluate this wholeness perceived in the images (Doesburg et al,. 2021). For this, we are evaluating the potential of proprioceptive (kinaesthetic) experience, i.e. the perception of one's own position, posture,

\footnotetext{
${ }^{3}$ Perradiation is the length and perceived tension of the gesture that can be sensed in the main branches that run from the centre towards the peripheral zone, where the movement fades out.
} 

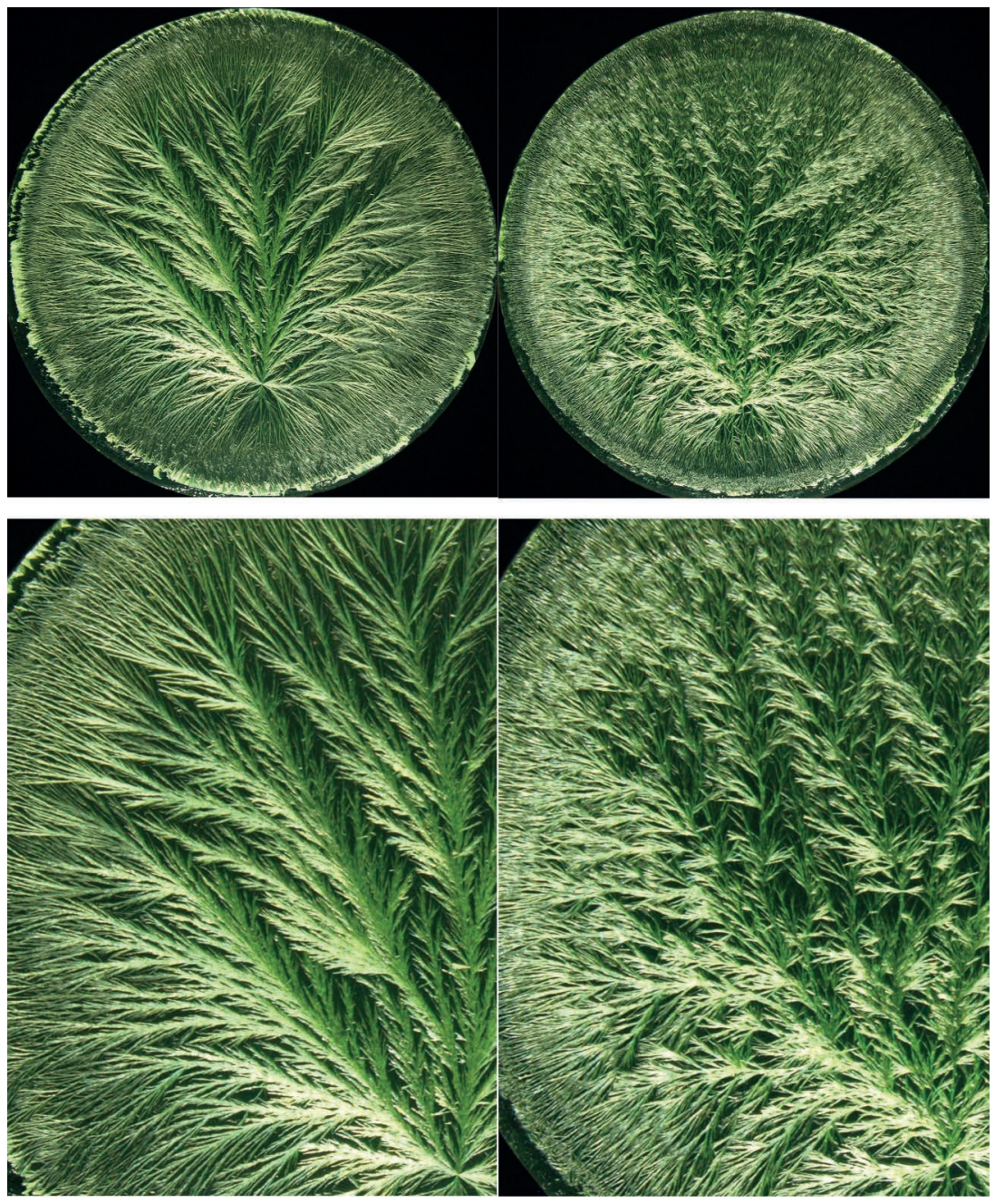

FIGURE 16.4 Crystallisation patterns of fresh (left) and aged carrot juice (right; after 7 days of storage at $\left.4^{\circ} \mathrm{C}\right)$. A loss of structure and organisation is apparent in the aged carrot juice.

equilibrium or internal condition applied to sense perception content instead of body self-awareness. It's comparable to the bodily sensation that we are all familiar with when, for example, affected by a dramatic gesture in an artwork. Proprioceptive experience, coupled with the emotional resonance it triggers, is likely to be a crucial component of our aesthetic experience of artworks (Freedberg and Gallese, 2007).

According to the 'growth-differentiation balance hypothesis', an optimal product quality is the result of a harmonious plant development (Bloksma et al., 2007). In the plant's development, two fundamental life processes can be distinguished: growth (mass formation) and ripening (flower and seed formation, flavour and scent). Within this, harmony refers to a balance between these two life processes by mutual influence. It's possible to learn to perceive the patterns by which these life processes express themselves (Doesburg et al., 2015). A harmonious plant development results in an integrated wholeness leading to resilient, crop-specific, tasteful products with a long shelf life (Bloksma et al., 2007). 


\section{THE INFLUENCE OF THE AGRICULTURAL METHOD}

The method also shows differences between products from conventional, organic and biodynamic origin. Organic/biodynamic agriculture wields a systemic approach which aims towards healthy and resilient plants and animals that have a strong immune system and thus omits the need for pesticides.

One aspect I often see in crystallisation images from products originating from conventional agriculture is that the differentiation phase seems to be missing. This phase, which can be considered the refinement or finishing touch of the crop's development, is irreducibly connected to a harmoniously developed product. These conventional products are often fertilised too heavily, causing a one-sided growth. Instead of quietly maturing, degradation trends already start to dominate in the growth phase. To put it more simply, the plants in which growth predominates act like a teenager with ageing symptoms (Figures 16.5 and 16.6). Such a crop is far more susceptible to disease and often does not reach the differentiation phase. It is in this phase that most health-promoting nutrients and aroma substances are formed, which influence taste considerably (Barański et al., 2017).

A justified question is whether harmonious crystallisation images of food samples have health benefits. In 2010, the Dutch government financed a research project 'Is organic more healthy?' (Huber et al., 2010b), to once and for all address the question of whether organic agricultural food products have an increased health benefit.

A feeding trial was performed with three genetically different groups of chickens over two generations. The chickens were fed with identically composed organic or conventional feeds. Although the animals constituting the two feeding groups were all healthy, differences between the groups were apparent. The conventionally fed chickens showed an overall higher weight gain than the organically fed chickens, even though feed intake of the two feeding groups and the metabolisable energy of the feeds were comparable. The animals of the second generation of both groups underwent an immune challenge, causing a significant reduction in growth rate. Yet the organically fed chickens, of all three genetic varieties, showed a stronger immune reactivity, as well as a significantly stronger 'catch-up growth' after the challenge, indicative of an increased resilience, compared to the conventionally fed chickens. Of the feed ingredients analysed with the crystallisation method, only two ingredients (soy and wheat) originated from a standardised field trial (i.e. the same location, seed variety and
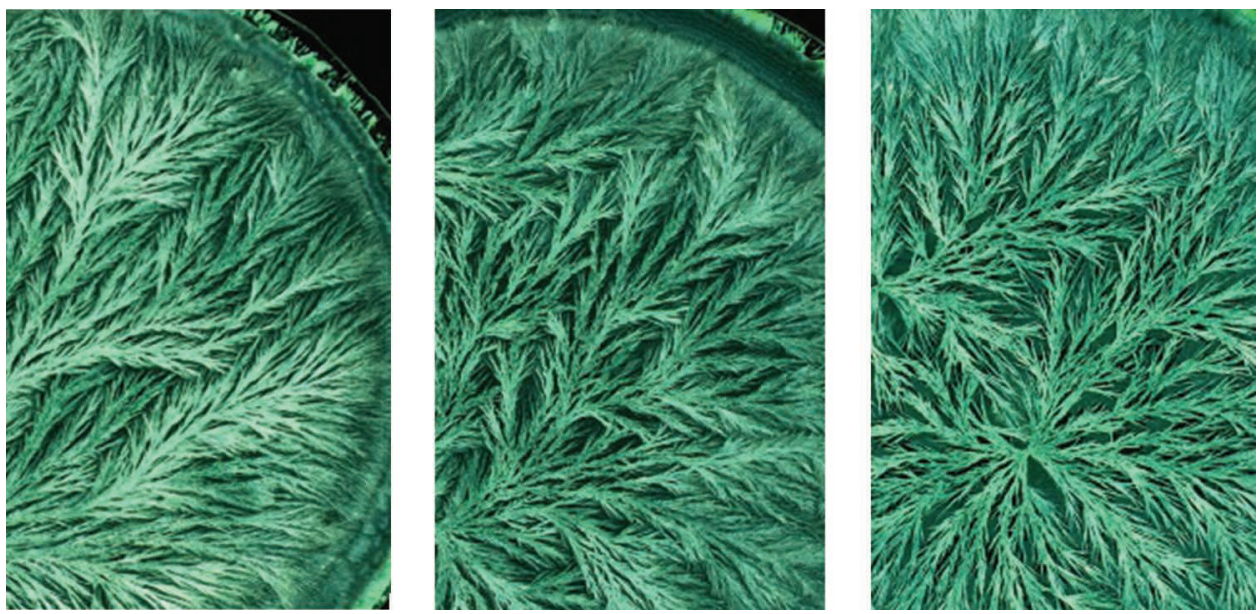

FIGURE 16.5 Enlarged details of crystallisation patterns of a wheat aging series. Left: fresh extract; middle: extract stored for 3 days at $4^{\circ} \mathrm{C}$; and right: extract stored for 12 days at $4^{\circ} \mathrm{C}$. The photos show a loss of structure and organisation as aging of the wheat extract progresses. 

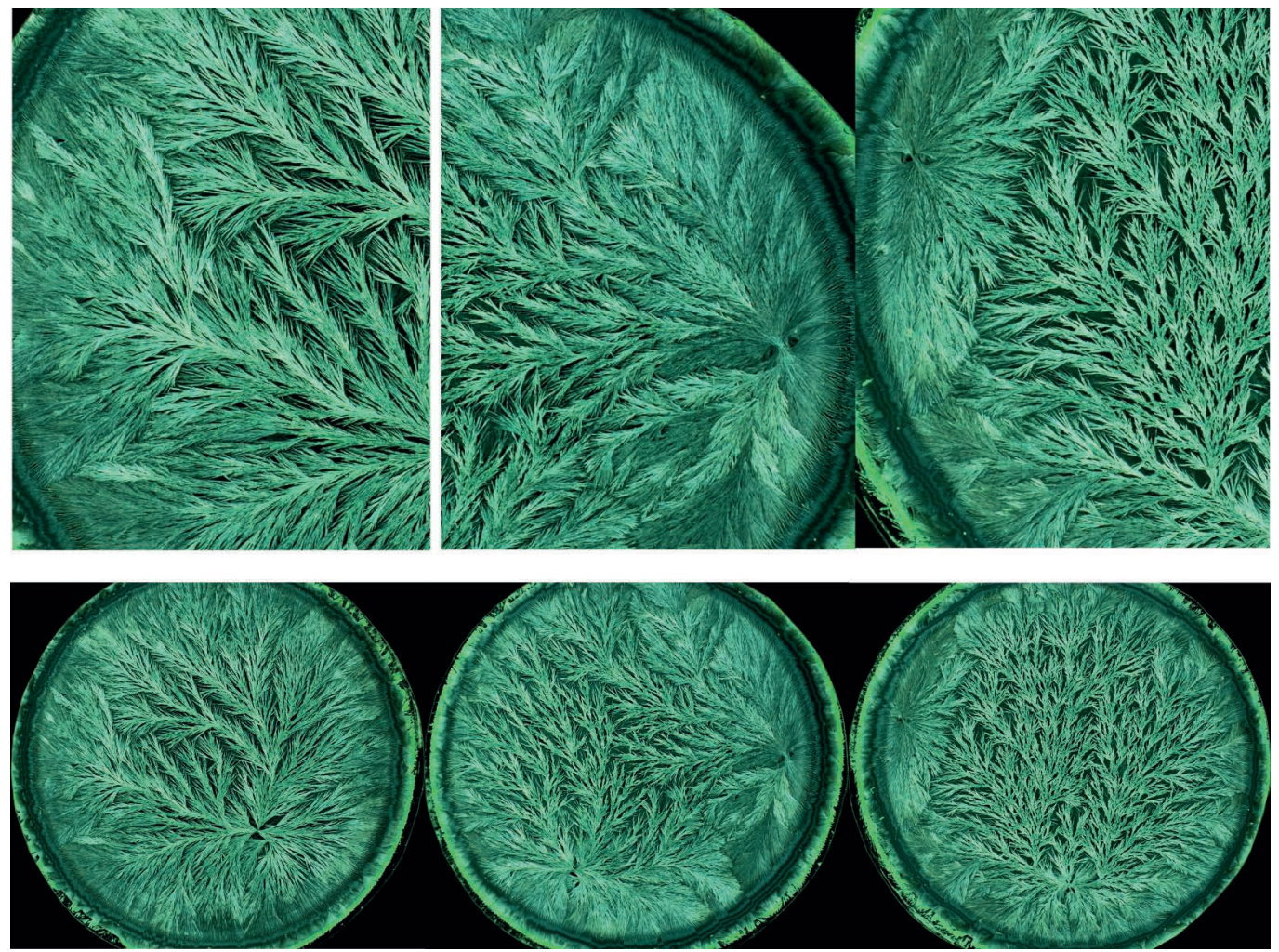

FIGURE 16.6 Crystallisation patterns of 12-day-aged wheat extract originating from a long-term DOC field study (FiBL, CH). Since 1978, wheat has been cultivated according to biodynamic (D), organic (O) and conventional (C) guidelines, in which soil and climate variations are ruled out. Photos bottom: whole images; and top: enlarged details. Biodynamic wheat (left), organic wheat (middle) and conventional wheat (right). The images show an increasing loss of structure and organisation which is minimal in patterns originating from the biodynamic wheat extract and maximal in the patterns from the conventional cultivation (for comparison, also consider the aging series in photo 5). (Images: J. Fritz, Uni Bonn, Germany.)

microclimate), allowing a fair comparison of the effect of the two farming systems on the resulting crystallisation patterns. For both soy and wheat, the visual evaluation clearly pointed to a superior quality of the organic ingredients, which of course is a very interesting find.

\section{A NEW PERSPECTIVE ON FOOD QUALITY}

The crystallisation method generates a physical image of the life processes inside an organism. Evaluating the crystallisation images appeals to one's morality when one sees the effect of the agricultural system and/or processing techniques, similar to the frequently applied Röntgen detection technique for the detection of foreign particles (metal, glass and plastics) in food. This opens up an entire field of research. There is a need for new research methods that can visualise or otherwise detect aspects such as vitality, resilience, individuality and self-regulation and make them broadly communicable. These aspects currently are not part of the remit of nutritional science, but the aim of my work is to contribute to broadening this scope, based on the understanding that life is not an ancillary element of chemical and physical processes, but actually expresses itself through these processes. Food is so much more than just a bag of nutrients! 


\section{REFERENCES}

Andersen, J.-O., Laursen, J. and Koelster, P. (1998) A refined biocrystallization method applied in a pictomorphological investigation of a polymer. Elemente der Naturwissenschaft 68: 1-20.

Andersen, J.-O., Henriksen, C. B., Laursen, J. and Nielsen, A. A. (1999) Computerised image analysis of biocrystallograms originating from agricultural products. Computers and Electronics in Agriculture 22: 51-69.

Andersen, J.-O., Kaack, K. V., Nielsen, M., Thorup-Kristensen, K. and Labouriau, R. L. (2001) Comparative study between biocrystallization and chemical analyses of carrots (Daucus carota L.) grown organically using different levels of green manures. Biological Agriculture and Horticulture 19: 29-48.

Applegate, C., Rowles Joe, I., Miller, R., Wallig, M., Clinton, S., O’Brian, W. and Erdman, J. (2019) Dietary tomato, but not lycopene supplementation, impacts molecular outcomes of castration-resistant prostate cancer in the TRAMP model (P05-015-19). Current Developments in Nutrition 3(Suppl 1): nzz030. P05-015-19.

Barański, M., Rempelos, L., Iversen, P. O. and Leifert, C. (2017) Effects of organic food consumption on human health; the jury is still out! Food and Nutrition Research 61: 1287333.

Barth, J. G. (1990) Empfindliche Kristallisation-Krebs und Prekanzerose. Elemente der Naturwissenschaft 52: $42-51$.

Baumgartner, S., Doesburg, P., Scherr, C. and Andersen, J.-O. (2012) Development of a biocrystallisation assay for examining effects of homeopathic preparations using cress seedlings. Evidence-Based Complementary and Alternative Medicine, 12. DOI: 10.1155/2012/125945.

Bloksma, J., Northolt, M., Huber, M., van der Burgt, G.-J. and van de Vijver, L. (2007) A new quality concept based on life processes. In Cooper, J., Leifert, C. and Niggli, U. (eds), Handbook of Organic Food Safety and Quality, pp. 53-73. Cambridge: Woodhead Publishing.

Boileau, T. W.-M., Liao, Z., Kim, S., Lemeshow, S., Erdman, Jr., J. W. and Clinton, S. K. (2003) Prostate carcinogenesis in N-methyl-N-nitrosourea (NMU)-testosterone-treated rats fed tomato powder, lycopene, or energy-restricted diets. JNCI: Journal of the National Cancer Institute 95: 1578-1586.

Busscher, N., Kahl, J., Andersen, J.-O., Huber, M., Mergardt, G., Doesburg, P., Paulsen, M. and Ploeger, A. (2010a) Standardization of the biocrystallization method for carrot samples. Biological Agriculture and Horticulture 27: 1-23.

Busscher, N., Kahl, J., Doesburg, P., Mergardt, G. and Ploeger, A. (2010b) Evaporation influences on the crystallization of an aqueous dihydrate cupric chloride solution with additives. Journal of Colloid and Interface Science 344: 556-562.

Busscher, N., Kahl, J. and Ploeger, A. (2014) From needles to pattern in food quality determination. Journal of the Science of Food and Agriculture 94: 2578-2581.

Busscher, N., Doesburg, P., Mergardt, G., Sokol, A., Kahl, J. and Ploeger, A. (2018) Influence of dewetting on the crystallization behavior of $\mathrm{CuCl}_{2}$ in the presence of BSA during evaporation in a Petri dish. Heliyon 5: 01102.

Doesburg, P. and Nierop, A. F. (2013) Development of a structure analysis algorithm on structures from $\mathrm{CuCl}_{2} \cdot 2 \mathrm{H}_{2} \mathrm{O}$ crystallization with agricultural products. Computers and Electronics in Agriculture 90 : 63-67.

Doesburg, P., Huber, M., Andersen, J.-O., Athmann, M., van der Bie, G., Fritz, J., Geier, U., Hoekman, J., Kahl, J., Mergardt, G. and Busscher, N. (2015) Standardization and performance of a visual Gestalt evaluation of biocrystallization patterns reflecting ripening and decomposition processes in food samples. Biological Agriculture and Horticulture 31: 128-145.

Doesburg, P., Andersen, J.-O., Scherr, C. and Baumgartner, S. (2019) Empirical investigation of preparations produced according to the European Pharmacopoeia monograph 1038. European Journal of Pharmaceutical Sciences: Official Journal of the European Federation for Pharmaceutical Sciences 137: 104987.

Doesburg, P., Fritz, J., Athmann, M., Bornhütter, R., Busscher, N., Geier, U., Mergardt, G. and Scherr, C. (2021) Kinesthetic engagement in Gestalt evaluation outscores analytical 'atomic feature'evaluation in perceiving aging in crystallization images of agricultural products. Plos one, 16(3): e0248124.

Freedberg, D. and Gallese, V. (2007) Motion, emotion and empathy in esthetic experience. Trends in Cognitive Sciences 11: 197-203.

Fritz, J., Athmann, M., Kautz, T. and Köpke, U. (2011) Grouping and classification of wheat from organic and conventional production systems by combining three image forming methods. Biological Agriculture and Horticulture 27: 320-336. 
Fritz, J., Athmann, M., Meissner, G., Kauer, R. and Köpke, U. (2017) Quality characterisation via image forming methods differentiates grape juice produced from integrated, organic or biodynamic vineyards in the first year after conversion. Biological Agriculture and Horticulture 33: 195-213.

Fritz, J., Athmann, M., Andersen, J.-O., Doesburg, P., Geier, U. and Mergardt, G. (2018) Advanced panel training on visual Gestalt evaluation of biocrystallization images: Ranking wheat samples from different extract decomposition stages and different production systems. Biological Agriculture and Horticulture 35: 21-32.

Gallinet, J. P. and Gauthier-Manuel, B. (1992) Wetting of a glass surface by protein adsorption induces the crystallization of an aqueous cupric chloride solution. Journal of Colloid and Interface Science 148: $155-159$.

Huber, M., Andersen, J.-O., Kahl, J., Busscher, N., Doesburg, P., Mergardt, G., Kretschmer, S., Zalecka, A., Meelursam, A., Ploeger, A., Nierop, D., van de Vijver, L. and Baars, E. (2010a) Standardization and validation of the visual evaluation of biocrystallizations. Biological Agriculture and Horticulture 27: $25-40$.

Huber, M., van de Vijver, L. P., Parmentier, H., Savelkoul, H., Coulier, L., Wopereis, S., Verjeij, E., van der Greef, J., Nierop, D. and Hoogenboom, A.P. (2010b) Effects of organically and conventionally produced feed on biomarkers of health in a chicken model. British Journal of Nutrition 103: 663-676.

Kahl, J., Busscher, N., Doesburg, P., Mergardt, G., Huber, M. and Ploeger, A. (2009) First tests of standardized biocrystallization on milk and milk products. European Food Research and Technology 229: 175-178.

Kahl, J., Baars, T., Bügel, S., Busscher, N., Huber, M., Kusche, D., Rembialkowska, E., Schmid, O., Seidel, K., Taupier-Letage, B., Velimirov, A. and Zalecka, A. (2012). Organic food quality: A framework for concept, definition and evaluation from the European perspective, Journal of the Science of Food and Agriculture 92: 2760-2765.

Kahl, J., Busscher, N., Hoffmann, W., Mergardt, G., Clawin-Raedecker, I., Kiesner, C. and Ploeger, A. (2014) Development and performance of crystallization with additives applied on different milk samples. Food Analytical Methods 7: 1373-1380.

Kahl, J., Busscher, N., Mergardt, G., Mäder, P., Torp, T. and Ploeger, A. (2015) Standardization and performance test of crystallization with additives applied to wheat samples. Food Analytical Methods 8: 2533-2540.

Kahl, J., Busscher, N., Doesburg, P., Mergardt, G., Will, F., Schulzova, V., Hajslova, J and Ploeger, A. (2016) Application of crystallization with additives to cloudy and clear apple juice. Food Analytical Methods 10: 247-255.

Koopmans, A. (1990) Pfeiffersche blutkristallisatien und malignom-bereitschaft. Elemente der Naturwissenschaft 52: 28-35.

Marzaleka, K., Doesburg, P., Starzonek, S., Szczepańska, J., Woźniaka, L., Lorezno, J.M., Skapska, S., Rzoska, S. and Barba, F.J. (2019) Comparative effect of supercritical carbon dioxide and high pressure processing on structural changes and activity loss of oxidoreductive enzymes. Journal of $\mathrm{CO}_{2}$ Utilization 29: 46-56.

Piva, M. T. (1994) Cupric chloride crystallization with human blood-study of pictures obtained in different pathologies. Elemente der Naturwissenschaft 61: 25-39.

Sauer, U., Heinemann, M. and Zamboni, N. (2007) Getting closer to the whole picture. Science 316: 550-551.

Schweizer, F., Andersen, J.-O. and Laursen, J. (2010) Beobachtungen bei der Kupferchloridkristallisation: vom "Eiweiß-Vorbild" zum "Kupferchlorid-Nachbild". Elemente der Naturwissenschaft 92: 62-92.

Seidel, K., Kahl, J., Paoletti, F., Birlouez, I., Busscher, N., Kretzschmar, U., Särkkä-Tirkkonen, M., Seljåsen, R., Sinesio, F., Torp, T. and Baiamonte, I. (2015) Quality assessment of baby food made of different preprocessed organic raw materials under industrial processing conditions. Journal of Food Science and Technology 52: 803-812.

Shibata, T., Takakuwa, Y., Tanaka, A., Iguchi, T., Kogure, M. and Ogawa, T. (1996) Doping effect of human blood on surface microstructure of cupric chloride dendrites grown from aqueous solutions. Journal of Crystal Growth 167: 716-718.

Shibata, T., Matsumoto, S., Kogure, M., Iguchi, T., Tanaka, A., Nagano, T. and Ogawa, T. (2000) Effects of diabetic human blood addition on morphology of cupric chloride dendrites grown from aqueous solutions. Journal of Crystal Growth 219: 423-433.

Szulc, M., Kahl, J., Busscher, N., Mergardt, G., Doesburg, P. and Ploeger, A. (2010) Discrimination between organically and conventionally grown winter wheat farm pair samples using the copper chloride crystallisation method in combination with computerised image analysis. Computers and Electronics in Agriculture 74: 218-222. 
Unluturk, S., Pelvan, M. and Unluturk, M. S. (2013) The discrimination of raw and UHT milk samples contaminated with penicillin $\mathrm{G}$ and ampicillin using image processing neural network and biocrystallization methods. Journal of Food Composition and Analysis 32: 12-19.

Velimirov, A., Huber, M., Lauridsen, C., Rembiałkowska, E., Seidel, K. and Bügel, S. (2010) Feeding trials in organic food quality and health research. Journal of the Science of Food and Agriculture 90: 175-182.

Vester, F. (1960) Zur Indikation biochemischer Vorgänge durch kristallisierendes Kupferchlorid. Experientia 16: $279-281$.

Whitworth, A. (2006) Micronutrients: To supplement, or not to supplement? JNCI: Journal of the National Cancer Institute 98: 230-232. 